欧 米の製紙工場 $(\mathbf{V})$
(9) Domtar Fine Papers 社 Cornwall 工場
(10) Canadian International Paper 社 Trois Rivieres|工場

米 谷

稔

\title{
Pulp and Paper Mills in America and Europe (V) \\ (9) Domtar Fine Papers Co. Cornwall Mill \\ (10) Canadian International Paper Co. Trois Rivieres Mill
}

Minoru Kometani

\section{(9) Domtar Fine Papers 社 Cornwall 工場}

本工場は Ontario 州 Cornwall にあり，パルプか ら紙までの一貫工場である。KP 設備, 抄紙機 6 台, コーターを有し, 上級紙, 板紙を生産しているが, 仕 上設備が特に充実している。1981 年の生産量は BKP $450 \mathrm{t} / \mathrm{d}$, 紙・板紙 800 t/d である（1981 年, Post's Pulp \& Paper Directory による)。

\section{最近の工場設備}

最近の工場状況として, 主要設備（1981 年版, Lockwood's Directory を参考にした）を次に述べる。

\section{1. 工場及調木}

$$
\begin{aligned}
& \text { 丸太の貯蔵 } \\
& 82,600 \mathrm{~m}^{3} \\
& \text { チップの貯蔵 } \\
& 35,400 \mathrm{~m}^{3} \\
& \text { 荷役用車輛 } \\
& \text { クローラークレーン } 3 \text { 台 } \\
& \text { ロッグローダー } 5 \text { 台 } \\
& \text { ロッグハンドリング } \\
& \text { チェーン及ベルトコンベヤー } \\
& \text { チップハンドリング } \\
& \text { チェーン及ベルトコンベヤー } \\
& \text { チップアンローダー } \\
& \text { レーダーニューマチックシステム } \\
& \text { レーダートラックダンパー } 1 \text { 台 }
\end{aligned}
$$

$$
\begin{aligned}
& \text { バーカー } \quad \phi 3.7 \mathrm{~m} \times 13.7 \mathrm{~m} \text { の } \\
& 2 \text { セクションのドラム } 2 \text { 台 } \\
& \text { チッパー カーセージ型 } \\
& 2,159 \mathrm{~mm} \mathrm{15} \text { 枚刃 } 1 \text { 台 } \\
& \text { リチッパー カーセージ型 } \\
& 1,219 \mathrm{~mm} 8 \text { 枚刃 } 1 \text { 台 } \\
& \text { チップスクリーン テーラー傾斜式 } 3 \text { 台 }
\end{aligned}
$$$$
\text { 皮にぎパルプ材 毎日使用量 } \mathrm{L} \text { 材 } 3,624 \mathrm{~m}^{3}
$$

2. パルプエ場

当工場は KP を製造している

2.1 蒸 解

バッチ式木釜

$102.0 \mathrm{~m}^{3} \quad 4$ 基

$79.3 \mathrm{~m}^{3} \quad 6$ 基

$\mathrm{KP}$ 日産 (晒, L材)

$450 \mathrm{t}$

2.2 薬品回収プラント

エバポレーター Swenson 6 重効用 1 台

7 重効用 1 台

回収ボイラ $\mathrm{B} \& \mathrm{~W} \quad 300 \mathrm{t} 1$ 缶 コープランド $180 \mathrm{t} \quad 1$ 缶

ガス洗浄器ベンチュリーサイクロン

石灰キルン D-O-L カルサイナー

石灰泥洗浄器 D-O-L 式 $3.0 \mathrm{~m} \times 3.7 \mathrm{~m} 1$ 台 苛性化システム Dorr-Oliver 式 苛性化槽 
白液 クラリファイヤー 3 槽

緑液 1 槽

2.2 漂白プラント

シーケンス

C-E-D-E-D

漂白塔

カミヤ アップフロー 3 塔 シェルブルップ

$$
\text { ダウンフロー }
$$

ミキサー

Impco 型, チタン被覆

ダブルシャフト

2 台

シングルシャフト

2 台

高濃度原質ポンプ $300 \mathrm{lmpco}$

2 系統

400 Impco

2 系統

$\mathrm{ClO}_{2}$ システム

Erco

2

能力 全部で, $10.5 \mathrm{t} /$ 日

2.3 パルプ処理

$$
\begin{array}{llr}
\text { ノッター } & \text { Jonsson } & 4 \text { 台 } \\
\text { スクリーン } & \text { Cowan centrifugal } & 3 \text { 台 } \\
\text { クリーナー } & \text { 第3 次用, 未晒システムに13 } \\
& \text { body のセントリクリーナー } \\
& & 1 \text { 式 }
\end{array}
$$

第 3 次用, 晒システムに 28

body のセントリクリーナー

1 式

ウオッシャー Impco 型 未晒系に

$4.2 \mathrm{~m} \times 8.0 \mathrm{~m} \quad 2$ 台

$3.5 \mathrm{~m} \times 4.9 \mathrm{~m} \quad 1$ 台

Impco 型 晒系に

$3.5 \mathrm{~m} \times 4.9 \mathrm{~m} \quad 4$ 台

リパルパー Kennedy Jones 型

$500 \mathrm{~kg} 1$ 台, $1,000 \mathrm{~kg} 1$ 台

パルプ乾燥

ウエットマシン Kamyr円網, 取幅 3,048mm

1 台

ドライヤー フラクト 1 台

カッター・レイボイ Lamb-Grays Harbor

取幅 $3,048 \mathrm{~mm} \quad 1$ 台

水圧式プレス Baldwin-United Steel

$600 \mathrm{t} \quad 1$ 台

Wire Tyers Griplock folder/tyer 1 台

Seales 1 台

\section{3. 製紙工場}

\section{1 原質調成室}

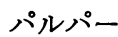

\begin{tabular}{|c|c|c|c|c|}
\hline 型 & $\begin{array}{l}\text { 網 幅 } \\
(\mathrm{m} \mathrm{m})\end{array}$ & $\begin{array}{l}\text { 取 幅 } \\
(\mathrm{mm})\end{array}$ & $\begin{array}{c}\text { 抄 逆 } \\
(\mathrm{m} / \mathrm{min})\end{array}$ & 台数 \\
\hline ダォブル & 2,159 & 1,829 & 109.7 & 1 \\
\hline D-E 長 網 & 4,267 & 3,759 & 350.5 & 1 \\
\hline$" \prime$ & 2,285 & 1,981 & 175.3 & 1 \\
\hline$" \prime$ & 3,912 & 3,429 & 320.0 & 1 \\
\hline " & 4,724 & 4,267 & 594.4 & 1 \\
\hline " & 4,877 & 4,369 & 670.6 & 1 \\
\hline \multicolumn{5}{|c|}{$2,000 \mathrm{~kg}$} \\
\hline & $2,000 \mathrm{k}$ & $\mathrm{BCK}$ & Hydrapul & r 1 台 \\
\hline
\end{tabular}

$500 \mathrm{~kg}$ Fulton

1 台

$500 \mathrm{~kg}$ Kennedy Jones 1 台 $1,000 \mathrm{~kg}$ Kennedy Jones 5 台
表 1 抄紙機一覧表

Dry End (broke)

$2,000 \mathrm{~kg}$ Sydrapulper 2 台

$2,000 \mathrm{~kg}$ Hydrapulper 1 台

$1,000 \mathrm{~kg}$ Kennedy Jones 2 台

リファイナー

7 台

ジョルダン

11台

クリーナー

3 次

4 本

2 "

2 本

サイズ釜 バッチ式 enzyme converting $2,500 \mathrm{~kg}$

2 台

\section{2 抄紙室}

抄紙機 6 台あり,これらを表 1 に示した。

$$
\text { コーター }
$$

$$
\text { オンマシン } 3,810 \mathrm{~mm}
$$

1 台

型式 Jagenberg Extended Blade

抄速 $457 \mathrm{~m} / \mathrm{min}$

日産 $240 \mathrm{t}$

オフマシン $2,438 \mathrm{~mm}$

1 台

型式 Beloit Flooded Nip

抄速 $305 \mathrm{~m} / \mathrm{min}$

日産 $90 \mathrm{t}$

3.3 仕 上 室

巻取包装設備 $\quad 2,159 \mathrm{~mm}$, Valley 自動包装機

リワインダー $2,921 \mathrm{~mm}$, Cameron 1 台 $1,905 \mathrm{~mm}$, Cameron 1 台 $1,270 \mathrm{~mm}$, Goebel 1 台 $1,524 \mathrm{~mm}$, Goebel 1 台

Sheeter 1,600mm Cut-size 3 台 1,600mm Folio Clark-Aiken 2 台 1,600mm Cut-size E.C.H. Will

1 台

2,210mm Cut-size E.C.H. Will

1 台

1,600mm Folio Jagenberg-

Clark A-iken 1 台 
$2,159 \mathrm{~mm}$ Masson Scott

2 台

$1,905 \mathrm{~mm}$ Jagenberg

2 台

$2,413 \mathrm{~mm}$ Jagenberg

Trimmer 2,159mm Seybold

1 台

2 台

連包装と Cartoning

Pemco cut-size

4 台

Hayssen cut-size

4 台

Stevens folio size wrappers

Case Packers

Case Sealers

Labellers

Strapping 設備

$\begin{array}{ll}\text { Acme skid wrapper } & 1 \text { 台 } \\ \text { Signode carton banders } & 2 \text { 台 } \\ \text { Columbia carton pallentizer } & 1 \text { 台 } \\ \text { Acme pallentizer-stretch } & \\ \text { wrapper } & 1 \text { 台 } \\ \text { 1,422mm, B.F.Perkins } & 2 \text { 台 }\end{array}$

Embosser 1,422mm, B.F.Perkins

\section{4. 動力設備}

\section{1 動力用ボイラ}

ボイラ

2 缶

然料

ガス, 石油

蒸気発生量

$290 \mathrm{t} / \mathrm{h}$

圧力

$14 \mathrm{~kg} / \mathrm{cm}^{2}$

4.2 重 気

$\begin{array}{lr}60 \text { サイクル } & 3 \text { 相 } \\ \text { 購入電気 } & 40,000 \mathrm{~kW} / \text { 日 }\end{array}$

\section{5. 用, 排水設備}

\section{1 用水処理}

\section{2 排水処理}

水源 セントローレンス河

毎日用水使用量 10.8 万 $\mathrm{m}^{3}$

一次処理 クラリファイヤー

$76.2 \mathrm{~m}$ (スラッジ脱水装置付) 1 台

\section{6. 製品及生産高}

ブリストル 箱抜紙 食品コンテナー, 塗被タバ コ板紙, ボンド, 帳簿用紙, 腾写版用紙, 複写紙, 教科書用紙, 表紙用紙, 書籍用紙, 平版印刷用紙, 軽量用紙, オフセット用紙, 封筒用紙, 会計簿記用 紙, 特殊紙類

以上 紙・板紙の生産高

$725 \mathrm{t} / \mathrm{d}$

1968 年の見学者 E.S. T.F. M.T. の三氏

工場全般, 特に仕上設備を主として見学した。見学後

の所見は次の通り。

1. カッター

カッターはいずれもリジェクト 2 次レイボイ付の ものを使用し, カッターの運転を止めずにパイルの 取出しを行い，連続運転方式をとっている。

2. スリッター（セルフホーニング）

7 号マシン（当時は 7 台のマシンがあった）のワ インダーにセルフホーニングスリッター (Smith self-honing slitter) を使用していた。その効果と してはスリッターナイフ（材質モネルメタル）の寿 命が永持ちすることである。すなわち次の通り。

普通型スリッターの場合 1〜2 日 セルフホーニングスリッターの場合１0～15日 セルフホーニングの機構（図 1 参照）

トップスリッターナイフは, ボトムスリッターナ イフに対して, 斜方向に脱着する。通紙のとき, 紙 がナイフで切られることがない。

Top Slitter Knite

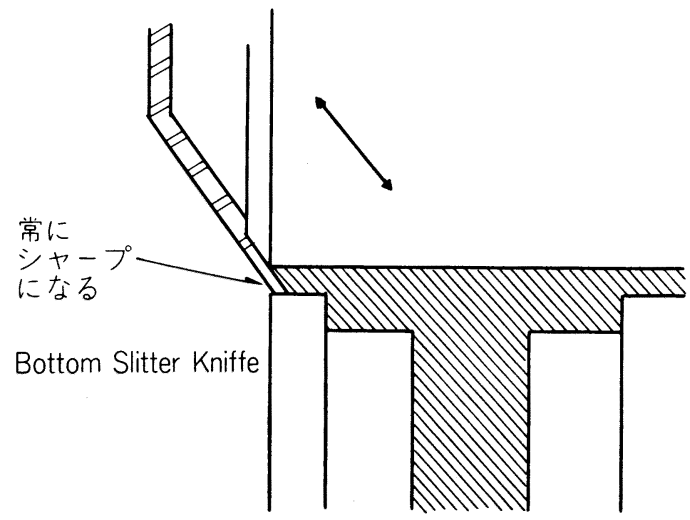

図 1 セルフホーニングスリッター

\section{(10) Canadian International Paper 社}

\section{Trois Rivieres 工場}

本工場は Trois Rivieres Qubec 州にあり，スプル ース，バルサムなどを使用, $\mathrm{Na}$ ベースで高歩留 SP を作り，一方マガジン砕木機でストーン GP を 作り，新聞用紙を抄造している。1981年において新 聞巻取紙並に板紙類 $1,000 \mathrm{t} /$ 日 を生産している。

\section{最近の工場設備}

最近の工場状況として, 主要設備 (1981 版 Post's Pulp \& Paper Directory, Lockwood's Pulp \& Paper Directory を参考にした）について次に述べる。 従業員 パルプ工場 115 人, 製紙工場 200 人 総従業員 1,250 人 
1. 土場及調木

皮はぎ丸太貯蔵能力 消費量

ドラムバーカー

チッパー 14枚刃

チップスクリーン
$566,400 \mathrm{~m}^{3}$ $2,596 \mathrm{~m}^{3} /$ 日

7 台 1 台 4 台

2. パルプエ場

バッチ式 SP 木釜 7 基 $\mathrm{SP}$ 平均生産量(末晒, $\mathrm{N}$ 材で)

$260 \mathrm{t} /$ 日

ストーン砕木機 29台 GP 平均生産量（未唒， $\mathrm{N}$ 材で）

$750 \mathrm{t} /$ 日

\section{3. 製紙工場}

\section{1 原質調成室}

パルパー 13台

ディスクファイナー 7 台

ジョルダン 6 台

スクリーン

3.2 抄 紙 室 抄紙機 表 2 に抄紙機を一覧表にして示す。

\section{3 仕上室}

ブレーカースタック

7 台

カレンダー 14台

ワインダー 9 台

リワインダー 2 台

スーバーカレンダー

1 台

ロールハンドリング設備

天井走行クレーン

ホイスト

フロアーコンベヤー

エレベーター

トラック

\section{4. 動力設 備}

\section{1 動力用ボイラ}

蒸気発生量

然料
$\mathrm{B} \& \mathrm{~W}$ 缶数不明 $200 \sim 300 \mathrm{t} / \mathrm{h}$ 石油, バーク
表 2 抄紙機一覧表

\begin{tabular}{|c|c|c|c|c|c|}
\hline 型 & 式 & $\begin{array}{l}\text { 網 幅 } \\
(\mathrm{m} \text { m) }\end{array}$ & $\begin{array}{l}\text { 取 幅 } \\
(\mathrm{m} \text { m) }\end{array}$ & 抄 $/ \mathrm{min})$ & 台数 \\
\hline \multirow[t]{3}{*}{ 長 } & 網 & 4,054 & 3,861 & 405.4 & 4 \\
\hline & & 4,054 & 3,861 & 487.7 & 2 \\
\hline & & 4,054 & 3,861 & 609.6 & 1 \\
\hline 円 & 網 & 2,096 & 2,032 & 38.1 & 1 \\
\hline \multicolumn{2}{|c|}{ Veriform } & 3,861 & & 609.6 & 1 \\
\hline
\end{tabular}

4.2 電気

タービン

2 台

電気消費量 $7 \sim 8$ 万 $\mathrm{kWh} /$ 日

5. 用 水

水源

河

$90 \%$

公営水道

$10 \%$

6. 製品

ロトグラビア新聞用紙

$969 \mathrm{t} /$ 日

工場包装紙，紙管原紙

$33 \mathrm{t} /$ 日

なおコアしん棒の製作，販売を行っている。

本工場は古い工場であるが新聞用紙抄造の専門工場 として定評あり，1952 1968年にわたり，見学者は次 の氏であった。

I. T., J. S., H. N., H. N., S. T., I. F., M. T. の諸氏

\section{工場の改善}

1） SP 蒸解に 1978 年頃までは $\mathrm{Ca}$ ベースであった が，その後 $\mathrm{Na}$ ベースに転換した。

2) 新聞巻取紙製造設備は改善された。

3） 5 号マシンのスピードアップ

新加圧ヘッドボックス, 脱気装置, 大型テーブルロ ール，新高負荷プレスロール，バキウムトランスファ 一, ドライヤー能力増加, バキュウムポンプ容量増加, ドライヤードレーン排出設備改善, アンプリダイン式 セクショナルドライブ設置等を行った結果, 第 5 号マ シン（新聞用紙抄造）は, 最初の設計抄速 $365.8 \mathrm{~m}$ に もかかわらず, 高効率で年間を通じて, $640.1 \mathrm{~m}$ 以上 で運転して世界記録を樹立した。 